\title{
Kenneth George Grimes (1944 - 2016)
}

\author{
Susan White \\ Victorian Speleological Association
}

Kenneth George Grimes grew up on a beef cattle property near Proston, Q1d, the youngest of a large family. His early schooling was by correspondence until he was 9 , followed by boarding school in Toowoomba for primary and then Brisbane Grammar School. At 'Grammar' he so disliked the inner city environment he was determined to work in the bush. As a result he studied geology and geomorphology at the University of Queensland on a cadetship from the Queensland Department of Mines, graduating with a BSc (Hons) in 1968. He undertook further studies in $1973-79$ mainly in geography and geomorphology. At UQ he took up caving with the University of Queensland Speleological Society (UQSS), joining such luminaries as Henry Shannon, Dave Gillieson, Tony Sprent and Michael Bourke.

From 1969 to 1991 he was a Geologist in the Regional Mapping Section of the Geological Survey of Queensland (GSQ) where he was assigned to the joint BMR-GSQ team that was charged with the task of mapping the Mesozoic and Cenozoic deposits of the Carpentaria and Karumba Basins of north Queensland. As part of that team, Ken undertook fieldwork throughout northwest Queensland, the Gulf country and Cape York Peninsula from 1969 to 1973. Ken made a major contribution to the interpretation of the Cenozoic geology and landscape development of the region by extending the use of duricrust stratigraphy, which had been developed by Brian Senior and others in south-western Queensland. He introduced the concept of cyclicity to the depositional and weathering regimes throughout the Queensland Cenozoic. Subsequent weathering geochronological studies are in general agreement with the scheme that he developed. It was this work that fostered his interest in pseudokarst.

Ken went on to apply his expertise to mapping Cenozoic deposits and regolith in central and southern Queensland. In the 1970s, this included the sapphire-bearing deposits of the Rubyvale area and the sand masses of the Fraser Coast region, including Cooloola and Fraser Island. He was one of the coauthors of Queensland Geology (Day et al, 1983. GSQ Publication 383), a companion volume to the 1976 1:2.5M Queensland Geology map.

In 1985, Ken's interest in karst combined with his skill in mapping Cenozoic deposits led to his involvement in research on the Tertiary Riversleigh fossil sites with Mike Archer and others. Ken made an important contribution through his ability to distinguish Cenozoic carbonate deposits from the Cambrian limestones on aerial photographs and in the field, thereby expanding the search area and leading to the discovery of several significant fossil vertebrate sites.

As early as 1973 he produced a report on Ashford Cave in far northern NSW, in which he subtly refuted any suggestion that it might replace (in either scientific or recreational terms) the Texas Caves, were they to be flooded by a dam. In 1978 Ken prepared a significant paper on the geology and geomorphology of the Texas Caves in SE Queensland, published by the Queensland Museum. This work benefited significantly from work done on the caves by UQSS and much of Ken's fieldwork was done in association with that society (which became defunct about the mid 80s).

Through most of the 1980s, he had a roving brief as a Cenozoic specialist attached to the various GSQ mapping teams. He became the department's expert on the Cenozoic and there are very few Queensland geology maps, which do not bear his name. Although subjected to friendly banter about 'mapping dirt' by the 'hard rockers' that dominated the teams, his skill in subdividing the otherwise blank areas of the map sheets was nonetheless valued as an essential input to any project. When it came to banter, Ken could give back as good as he received, but was always ready to share his knowledge and, apart from the many maps, reports and papers that he contributed to, his geological legacy in Queensland lives on in the influence he had on those who adopted and continued to use his approach to mapping the Cenozoic. His scheme for regolith unit compilation was used for the Geoscience Australia's 1:1M digital surface geology map of Australia (2009).

Having grown up on a grazing property, Ken was a natural bushman and this served him in good stead working as a young geologist in Cape York Peninsula, far from assistance if anything went wrong. In later years, he could be relied on to turn up to rescue colleagues who found themselves in difficulties, such as hopelessly bogged, hung up in some wash-out or with a flat battery or mechanical problems. Therefore, 


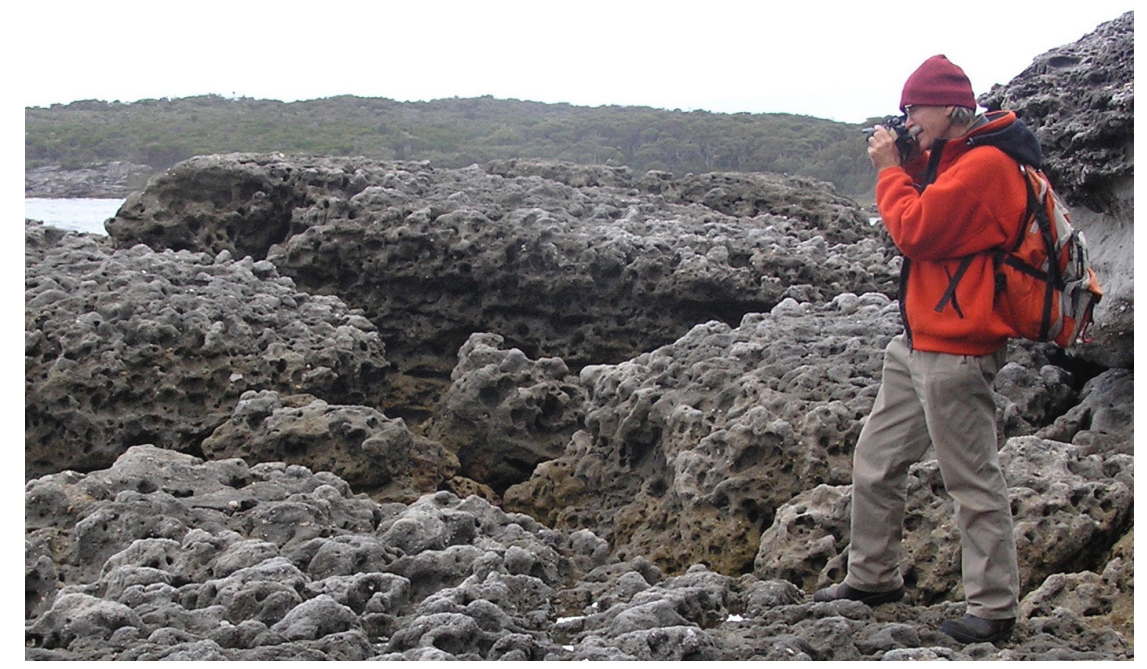

Ken Grimes on sandstone karst at Jervis Bay in New South Wales (photo: R.W. Young).

it was somewhat embarrassing for him, when mapping on Fraser Island in the mid-1970s, his vehicle became bogged in a creek at low tide. The hapless vehicle was submerged by several high tides before it could be retrieved, eventually towed out by a landing barge! In the pre-GPS days and using black-and-white, smallscale aerial photographs, Ken was a skillful navigator through the featureless bush that characterises much of the Cenozoic in outback Queensland. Although tending to be quiet in the office, Ken was a good companion around the camp-fire with his dry wit, and his culinary skills with the camp-oven were legendary.

It was a great loss to GSQ when Ken left in 1990, and moved to western Victoria with Janeen. This move however did have some advantages; he was able to specialize more on karst and had limestone and volcanic caves close by. His consulting expanded with more cave and karst work in various places: Naracoorte SA, lots of places in Victoria, Tasmania, and Christmas Island to name a few. His interest in volcanic caves grew and he has been involved in exploration, documentation and working out the processes involved in basalt cave formation. He was involved in a major study with Robert Wray, Andy Spate and Ian Houshold on the sandstone pseudokarst of northern Australia, a very under studied but fascinating area.

As he loved outdoor activities (but NOT competitive sport!) he joined the bushwalking and caving clubs at the University of Queensland where he met Janeen and they married in late 1970. As a member of the various caving clubs, UQSS, and later VSA, CCV, and CEGSA, he has been a stalwart speleologist. He received the Edie Smith Award in 2009 for his outstanding service to Australian speleology over many decades. He was involved in Australian Speleological Federation as convenor of the Surveying and Mapping Standards Commission of the Australian Speleological Federation, and was Queensland co-ordinator of the Australian Karst Index for the period 1975-1991. He has been a co-editor of Helictite, the Journal of Australasian Speleological Research since 1999. He was also a Fellow of the Australian Cave \& Karst Management Association. Many of us have copies of the well-illustrated field guides for various cave and karst meetings in western Victoria and SE South Australia. We have also listened to his interesting and well illustrated talks at ASF conferences and other meetings.

He has published many papers and reports on caves and karst and was a widely respected speleologist especially, but not exclusively in the Cainozoic karst, volcanic and pseudokarst areas. In particular these include Australian cave \& karst areas in general, karsts of eastern and northern Australia, tropical karren and microkarren, tropical island karst, karst hydrology, karst in less consolidated limestones including syngenetic karst, pseudokarst terminology, lava caves and has written or edited a series of Field Guides to the karst \& pseudokarst of southeastern South Australia and western Victoria. In 2012 he wrote for and edited the Helictite volume on the Proterozoic Northern Territory Judbarra / Gregory Karst, which contains Australia's longest cave system. He has published extensively on the karst in the dune limestones of southern Australia. As a Research Associate in the Environmental Geoscience group at Latrobe University, he was very generous with his time and assistance to post graduate students.

He was a member of GSA and since coming to Victoria has been a corresponding member of the Geological Heritage subcommittee with a very real interest in the geological heritage of the volcanism of western Victoria. His talks to the Victorian Division, delivered wearing his 'volcanic' beanie, were greatly appreciated.

Ken was also a very accomplished artist. He always drew; in the margins of books and on the walls and furniture of the old homestead. His cartoons were brilliant and included his quirky sense of humour; some of the recent ones can be seen on the Hamilton Field Naturalists website! He was a keen photographer.

Ken was a wonderful person who had the ability to communicate his vast knowledge and wisdom to people right across the spectrum of scientific understanding; an eminent, witty and a very active cave explorer and thinker. He was very generous with his time and knowledge to visitors to the lava and limestone cave areas of western Victoria and various geologists needing advice. We all valued him as a great 
friend, very generous with his knowledge, information and well-drafted cave maps which he made freely available to all.

Ken was killed on 17 August by a falling tree on their property near Hamilton, Victoria, while clearing a couple of jammed fallen trees. I still have difficulty believing we have lost so suddenly such a good friend and huge contributor to the understanding of the natural world. Ken's presence will be missed enormously by the entire speleological and geological community, and especially those of us who have worked closely with him. 